\title{
Poverty And Inequality In Access To Housing In Mexico City During Neoliberalism
}

https://doi.org/10.21272/sec.4(2).31-43.2020

Carlos Sanchez, ORCID: https://orcid.org/0000-0003-3319-9303

PhD Candidate, Professor of Economics, Faculty of Economics, National University of Mexico, Mexico

\begin{abstract}
The article is devoted to the main preconditions for the emergence of poverty and inequality in the distribution of housing among the population in Mexico City. The article analyzes this issue under the influence of the evolutionary development of neoliberalism: deindustrialization, depopulation and poverty. The study proposes a definition of the poverty index induced by housing shortages, which is calculated as the difference between the average annual income in a given locality and the average annual level of rent, loan and housing loan, which is related to the cost of food and non-food products. The study was based on statistics on income and housing of 16 districts, grouped into three functional areas of Mexico City for the period from 2008 to 2015, and the source of the study - analytical reports of the National Institute of Statistics and Geography of Mexico. The results of the empirical study show that deindustrialization is determined by an increase in the share of the tertiary sector of the economy and at the same time a reduction in material production. These trends in the sectoral development of the economy have led to a concentration of services in the city and uneven regional development, which has been accompanied by increasing speculation in the real estate market and the lack of an effective state housing policy. It has been established that over the last decade, conditions have been created in central Mexico for the expulsion of local low-income groups and the involvement of people with greater financial means. At the same time, locals in the southern district of Mexico City find themselves in a situation of deep inequality compared to residents of other parts of the city, as its residents have enough income to meet basic needs, so they are on the brink of poverty and socially vulnerable. The results of the study can be useful for scientists and government officials to take a set of measures aimed at stimulating housing construction for the poor.
\end{abstract}

Keywords: poverty, inequality, housing, neoliberalism, Mexico.

JEL Classification: I32, P16, R21.

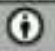

-

This work is licensed under a Creative Commons Attribution 4.0 International License.

Cite as: Carlos Sanchez (2020). Poverty And Inequality In Access To Housing In Mexico City During Neoliberalism. SocioEconomic Challenges, 4(2), 31-43. https://doi.org/10.21272/sec.4(2).31-43.2020.

(C) The Author, 2020. This article is published with open access at Sumy State University.

\section{Introduction}

In the rise of globalization, neoliberalism eroded Mexico City as a central scale in order to join the supranational scope without the direct mediation of the State. This distorted the urban in the City, because of a set of chained events: deindustrialization, depopulation and poverty. Thus, the rise of the market as a representative of the social brought with it a pattern of uneven development, affecting the production of housing and distorting its public policy. The withdrawal of the State and its institutional framework places the inhabitants of Mexico City in different degrees of poverty and social inequality induced by their lack of housing according to the area of the city they inhabit.

Therefore, this work includes two objectives developed in its two sections. The first is to understand the chained events that shaped differential access to housing in Mexico City and its 16 counties grouped into three functional areas. Central City, which includes four counties and is the most economically dynamic nucleus of the City; six adjacent counties that embrace the central nucleus; and six more counties or Southern Counties, which represent the largest area of the City and house its rural area. The second objective is to measure and 
map the differentiated impacts that the set of events has had on the conditions of poverty and inequality of the population caused by lack of housing in the 16 counties of the City and its functional areas from 2008 to 2015.

The results presented here warn about the need to return to the role of the State in the stewardship of public housing policy based on a new institutional framework that strengthens its actions in order to balance territorial inequalities in access to the housing of the inhabitants of Mexico City.

\section{Deindustrialization, depopulation and poverty: the way neoliberalism shaped housing policy in Mexico City}

Until before the decade of the eighties of the twentieth century, Mexico sustained a development model based on industrialization by import substitution with an important State intervention. Once the crisis of the eighties entered, the economic model restructured and with it the social political orientation of the State, which had an impact on the population, as well as on the housing policy and poverty conditions of the country's inhabitants. Arguing that it was necessary to deregulate the sectors of the economy to boost capital accumulation and thereby recover from the crisis, the market answer to the social needs was neoliberalism: trade liberalization, economic theory of comparative advantages and the minimum State.

The undertaking of a neoliberal development path in Mexico involved the elimination of subsidies to the population and the privatization of pensions, turning this fund into a system of individual capitalizations managed by private entities. The application of these measures, far from improving the situation of families, exacerbated poverty and conditions of economic inequality in several sectors. The abandonment of the selfsufficiency strategy for development radically transformed Mexico's relationship with other economies worldwide, moving from self-reliance to dependence, accompanied by the signing of the North American Free Trade Agreement (NAFTA) (Boltvinik, 2012). Since 1982, the deregulation strategy imposed the idea that the living standards of the population would improve through the liberation of the markets, the suppression of State intervention and the economic takeoff derived from the commercial opening. Neoliberalism placed Mexico as the country with the largest number of commercial treaties signed in the world, which encouraged the progressive dismantling of the limited national industry and sectoral control instruments.

Federal public investment fell from $10.4 \%$ of GDP in 1982 to $4.9 \%$ in 1988 , and $2.5 \%$ in 2002. Public spending on general economic sector development (concept that includes agricultural, manufacturing and energy sector development) was reduced from $11.9 \%$ of GDP in 1982 to $8.7 \%$ in 1988, and $3.7 \%$ in 2002 (Calva, 2004). Although this liberalization had an impact on the increase in exports from 14\% of GDP to $25.3 \%$ in 2002 , this improvement did not reflected in economic growth, since during this period, GDP only increased 0.56 times, at an average annual rate of $2.3 \%$. In contrast, during the industrialization by import substitution strategy (1935-1982), GDP increased 15.9 times, at an average annual rate of 6.1\% (Calva, 2004).

In this context, deindustrialization accompanied by economic liberalization played a key role in the increase or tertiary activities of the economy of Mexico City and a new population dynamics at the federal and local levels, which modified the objectives of housing and social development policies. Thus, from 1980 onwards, the Mexican population continued to grow with a dynamic of deceleration and demographic control, from which it went from 66 million inhabitants in 1980, to 81 million in the 1990s, and 91 million in 2000 to 103 million in 2010 (INEGI, 2017).

At the local level, until the mid-1970s Mexico City was still a privileged scale in the new industrial establishments, it was until the 1980s that the deindustrialization process reflected in the economic variables. This slow but progressive deindustrialization of the City is the result of a trend of relocation of the industry in the metropolitan area, accompanied by a readjustment in the spatial distribution of the population.

Although this dynamic did not end with the total expulsion of the industry, it influenced to diminish it considerably, since some City counties maintained an important participation in certain activities of the industrial sector, oriented largely to supply the local and national market. With this process, there was a growth in the activities of the tertiary sector such as commerce and services. From 1980 to 1988, although at a national level there was an increase in activities of the industrial sector in 3.8\%, this did not reflected in Mexico City, where that growth was barely just $0.03 \%$ per year (Williams, 1997). 
Deindustrialization had an impact on all counties in Mexico City: Cuauhtemoc as a central county deindustrialized in almost all subsectors, although the infrastructure conditions of the county led to the persistence of industrial activity like printing presses, publishing houses and clothing manufacturing. Miguel Hidalgo as a central county too and Azcapotzalco as an adjacent county have a strong industrial trajectory that also lost industry participation in several branches with the exception of printing and publishing, accompanied by a moderate growth of the wood industry and products derived from it. Gustavo A. Madero and Iztacalco as an adjacent counties had a loss in the concentration of jobs in the industrial sector, however, they recorded an upward participation of the garment and plastic products, cellulose, paper and derivatives manufacturing industries. The adjacent county of Iztapalapa maintained the metal products industry, the chemical industry, the paper industry, printers and publishers, in accordance with the trend in other counties. Between 1988 and 1994 there was an increase in jobs in the branch of the food industry (mainly bakery products), and the textile industry. While in the central county of Benito Juarez, deindustrialization progressed, maintaining the publishing industry. Finally, the southern counties that maintained an industrialization process were Tlahuac and Xochimilco, which in 1994 saw an increase in industrial employment, Tlahuac specializing in the industrial sector and Xochimilco in the chemical and pharmaceutical industry. This dynamic of location of the activities had consequences in the population derived from the type of activity concentrated in each county, recording important variations per decade.

This deceleration scenario expresses population dynamic in Mexico City as follows: the population growth rate remained on average below 3\%, with 2.5\% from 1980 to $1990 ; 3.04 \%$ from 1990 to $1995 ; 1.27 \%$ from 1995 to 2000; and $1.49 \%$ from 2000 to 2010 . This dynamic is explained by the growth of tertiary activities of the economy in these decades, which tends to disperse the demographic component, in addition to the industry moving to the outskirts of the City, encouraging a dispersion of the demographic concentration as shown in Table 1.

Table 1. Population evolution by counties in Mexico City $1990-2010$

\begin{tabular}{|l|c|c|c|c|c|}
\hline \multicolumn{1}{|c|}{ County or functional area } & 1990 & 1995 & 2000 & 2005 & 2010 \\
\hline Cuauhtemoc & 595,960 & 540,382 & 516,201 & 521,348 & 531,831 \\
\hline Miguel Hidalgo & 406,868 & 364,398 & 352,640 & 353,534 & 372,889 \\
\hline Venustiano Carranza & 519,628 & 485,623 & 462,806 & 447,459 & 430,978 \\
\hline Benito Juarez & 407,811 & 369,956 & 360,478 & 355,017 & 385,439 \\
\hline Central counties & $1,930,267$ & $1,760,359$ & $1,692,125$ & $1,677,358$ & $1,721,137$ \\
\hline Azcapotzalco & 474,688 & 455,131 & 441,008 & 425,298 & 414,711 \\
\hline Gustavo A. Madero & $1,278,888$ & $1,256,913$ & $1,235,083$ & $1,193,161$ & $1,185,772$ \\
\hline Alvaro Obregon & 640,749 & 676,930 & 686,783 & 706,567 & 727,034 \\
\hline Iztapalapa & $1,490,499$ & $1,696,609$ & $1,768,785$ & $1,820,888$ & $1,815,786$ \\
\hline Coyoacan & 640,066 & 653,489 & 640,423 & 628,063 & 620,416 \\
\hline Iztacalco & 448,322 & 418,982 & 411,288 & 395,025 & 384,326 \\
\hline Adjacent counties & $4,973,212$ & $5,158,054$ & $5,183,370$ & $5,169,002$ & $5,148,045$ \\
\hline Xochimilco & 265,131 & 327,290 & 358,223 & 404,458 & 415,007 \\
\hline Tlalpan & 484,544 & 552,395 & 581,397 & 607,545 & 650,567 \\
\hline Tlahuac & 209,013 & 257,572 & 308,786 & 344,106 & 360,265 \\
\hline Magdalena Contreras & 195,041 & 211,898 & 221,979 & 228,927 & 239,086 \\
\hline Cuajimalpa & 114,385 & 136,873 & 151,222 & 173,625 & 186,391 \\
\hline Milpa Alta & 66,524 & 84,100 & 99,437 & 115,895 & 130,582 \\
\hline Southern counties & $1,334,638$ & $1,570,128$ & $1,721,044$ & $1,874,556$ & $1,981,898$ \\
\hline Total, Mexico City & $8,238,117$ & $8,488,541$ & $8,596,539$ & $8,720,916$ & $8,851,080$ \\
\hline
\end{tabular}

Source: Own elaboration with Mexican official census information INEGI.

Because of a re-densification policy in Mexico City between 2000 and 2006, there was a recovery of the population growth rate in the central counties from $-17.9 \%$ in 1990 to $2.6 \%$ in 2010. In the adjacent counties, there is a process of contraction of the population growth rate, due to the combination of a recovery process of the growth rate in some counties such as Gustavo A. Madero, Iztacalco and Azcapotzalco; while there is a decrease in other counties such as Iztapalapa, Alvaro Obregon and Coyoacan (see Figures 1 and 2). In the case of the southern counties of Mexico City, a reduction in the population growth rate from $40.2 \%$ in 1990 to $9.6 \%$ in 2000 , and $5.7 \%$ in 2010 is noticeable (see Figure 3). 


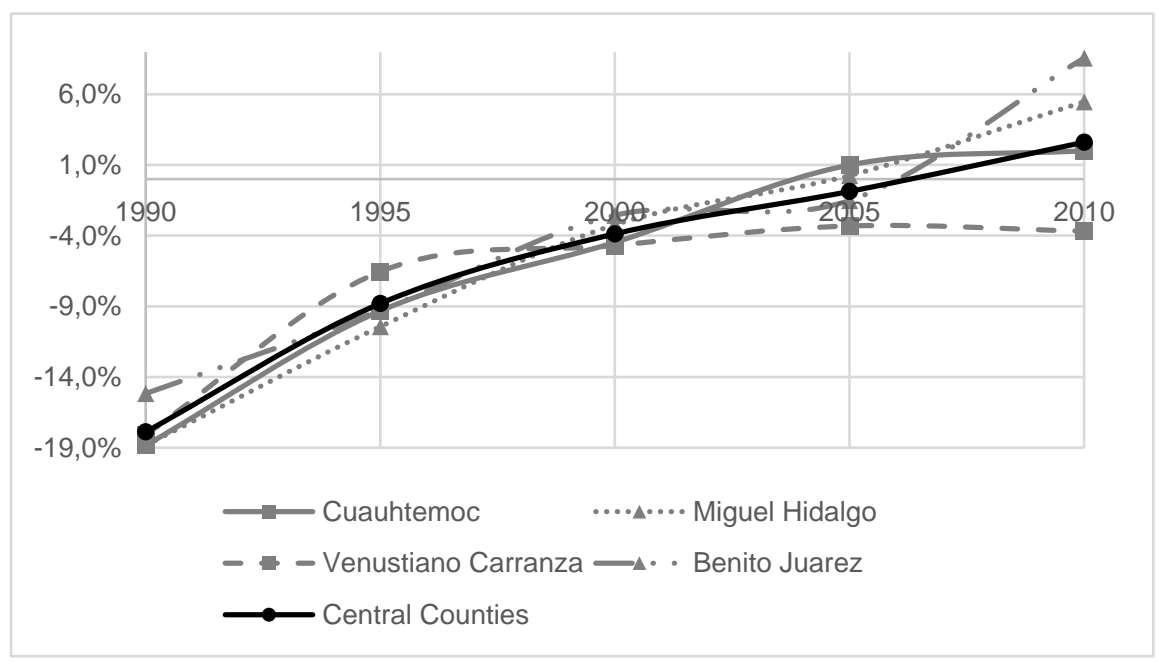

Figure 1. Evolution of the population growth rate in Mexico City 1990-2010 (Central Counties)

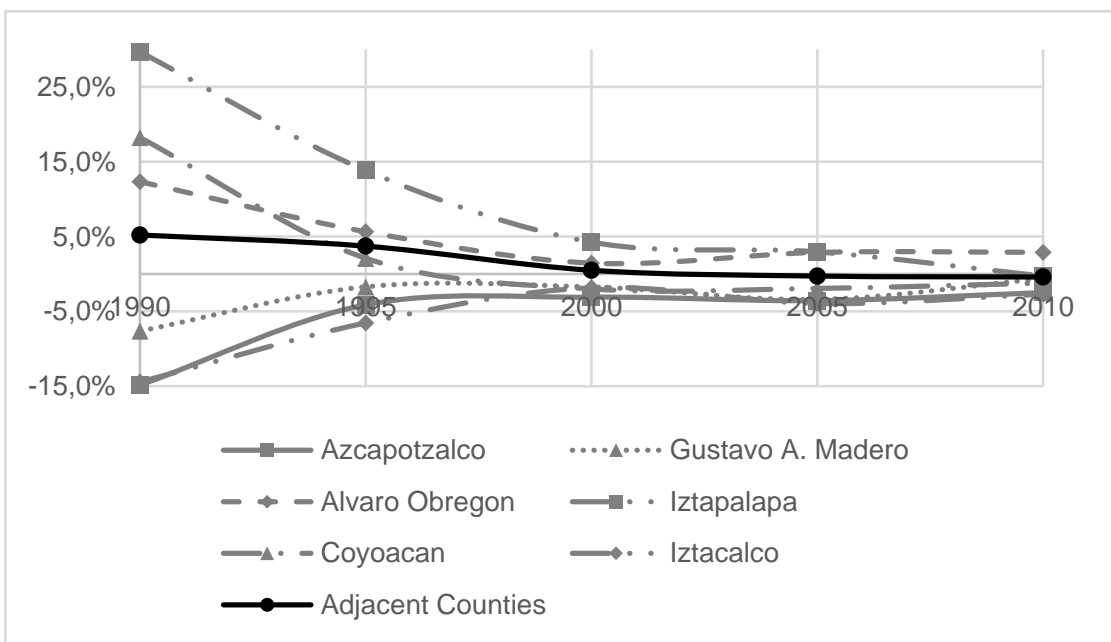

Source: Own elaboration with data from Table 1.

Figure 2. Evolution of the population growth rate in Mexico City 1990-2010 (Adjacent Counties) Source: Own elaboration with data from Table 1.

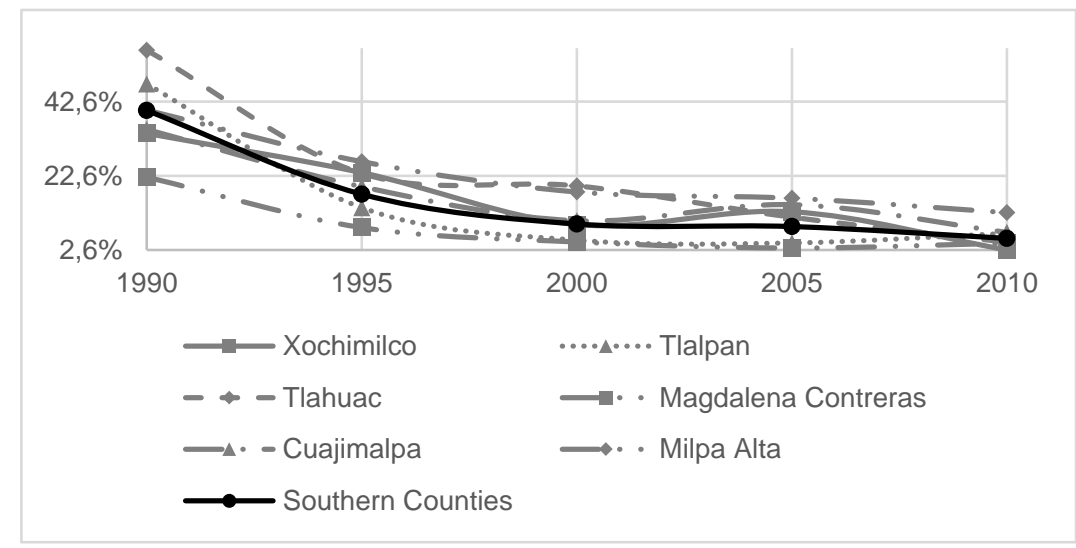

Figure 3. Evolution of the population growth rate in Mexico City 1990-2010 (Southern Counties) Source: Own elaboration with data from Table 1. 


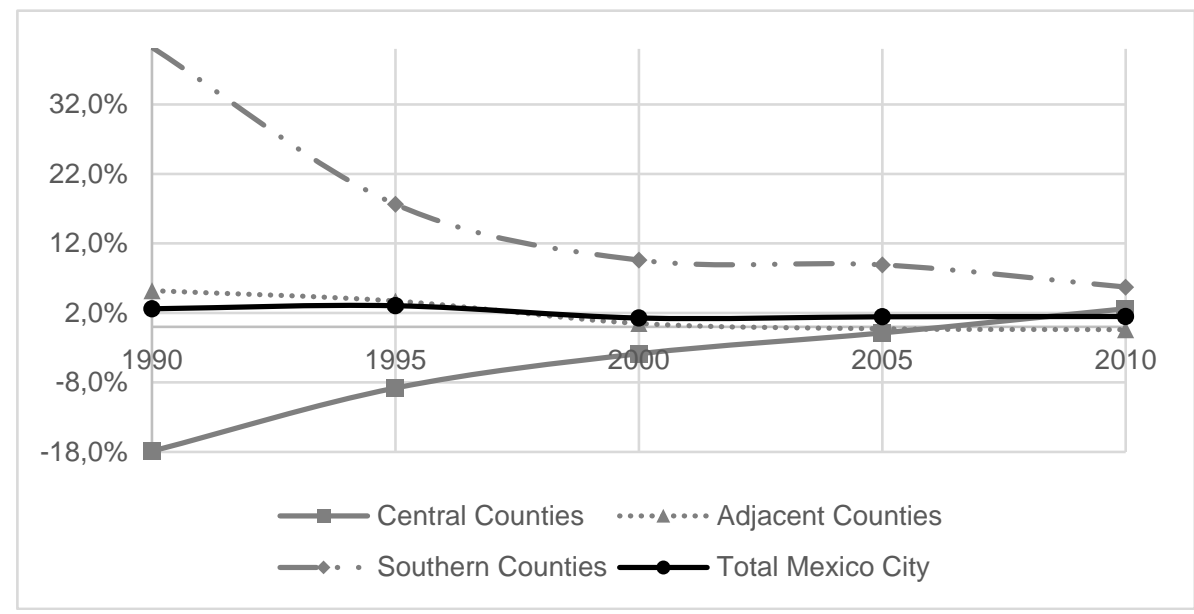

Figure 4. Evolution of the population growth rate in Mexico City 1990-2010 (Counties or Functional Areas)

Source: Own elaboration with data from Table 1.

Thus, each level of industrialization corresponds to a degree of centralization and demographic concentration that not necessarily establishes in the industrialized zone. In this way, the following population analysis periods for Mexico City are established: the first goes from 1950 to 1970 and describes the growth of industrial activity in the "central city", which stimulated population growth in some counties with greater industrial participation, accompanied by a depopulation in counties with little influence in the industry. The second describes a trend of relative decrease, which goes from 1970 to 2000, where there is a demographic rearrangement in a certain parallel with the deindustrialization and boom of the activities of the tertiary sector of the City's economy. During this period, some counties noted negative growth rates. Finally a third period from 2000 to 2010, where it is possible to distinguish a dynamic of re-densification, accompanied by a concentration of tertiary activities at the local level, encouraged by a compact city housing policy. Figures 4 and 5 show this dynamic by contrasting the growth rates in the groups of counties by functional area from the first decades of the second half of the 20th century to the recent years.

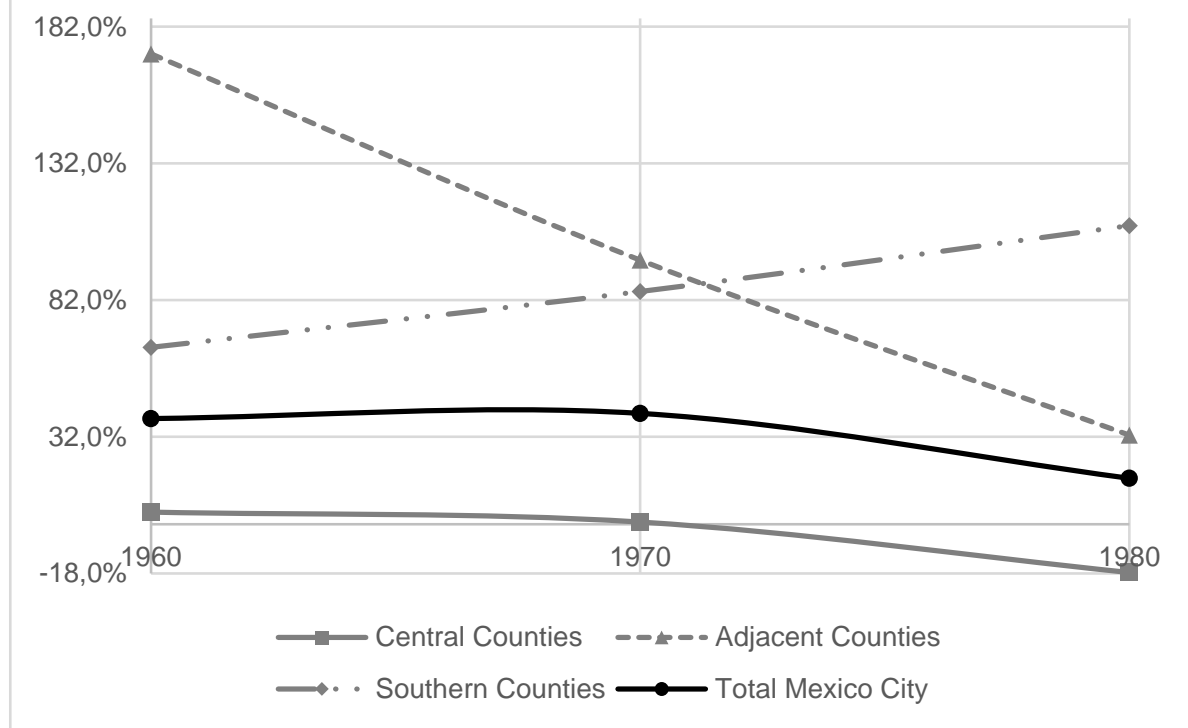

Figure 5. Evolution of the population growth rate in Mexico City 1960-1980 (Counties or Functional Areas)

Source: Own elaboration with data from Graizbord, 1991 and INEGI.

In the midst of this population trend in the City, and during the country's transit to a neoliberal development path towards the 1990s, minimum social housing appeared as an "efficient" market response to reduce urban poverty and improve the quality of life. It was the result of an approach based on free market thinking that 
reduced and replaced the concept of "social housing" with "minimum housing". The housing policy model prioritized the quantitative aspect of housing with emphasis on the mass production of large urban complexes, which implied the reduction of the quality of the physical space, the quality of the materials and the habitability conditions. This model of housing production shaped the purpose and characteristics of the housing sector and consequently the housing policy of the country, as shown below.

In Mexico, the housing sector plays an important role in the economy because it directly influences economic growth and job creation. According to the "Housing Satellite Account of Mexico 2015", the market and nonmarket activities accounted in the sector indicate that housing represented 5.9\% of GDP. Within this area, $60.2 \%$ of this proportion corresponded to the production of goods and services for the market (the construction of the private sector); while $38.7 \%$ corresponded to the production for the final use of households (selfconstruction, expansion, improvement, etc.); and the remaining $1.1 \%$ to non-market production (social housing provided by the government). The activities related to this sector constituted $6.8 \%$ of the country's occupation.

For INEGI, if the recommendations of the 2008 System of National Accounts are taken into account and rent (imputed) is included within the GDP of housing, it would represent $13.9 \%$ of the GDP of the economy in 2015 (INEGI, 2017). According to the latest estimates, the GDP of housing represents $14.1 \%$ of the national GDP, and generates more than 3 million jobs, influencing nearly 78 branches of the economy (Caballero, 2016). This fact emphasizes that the housing sector is predominantly private, where the housing production and circulation industry, in addition to having a large, profitable and constantly growing market, does not reflect an important social participation, which leaves access to housing to the self-regulated market.

From the year 2000, the housing sector at national level with its housing policy presents two trends. The first goes from 2000 to 2011, where there is a real estate boom and a significant growth in the sector through policies oriented to the construction of houses in volume. This policy integrated factors such as: "a) Construction of affordable housing to meet the demand and promote the housing sector that was lagging behind, b) Promotion of national housing organizations made up of various institutions, c) Promote the offer of housing in volume and in accordance with the purchasing power of the population "(Caballero, 2016 ). In this period, with the objective of encouraging the acquisition of new housing, development companies and housing policy established a line of credit oriented to families with incomes below four minimum wages. This channeled efforts to low-cost projects that many developers located in remote areas of the cities to offer lowcost housing, thereby achieving a growing profitability given the increasing volume of inventory that managed to place in the market. This model echoed the overproduction of housing that triggered the crisis in the real estate sector in the United States, with the difference that in Mexico the location of the developments was oriented to the creation of new residential areas in spaces never before urbanized.

The second period is from 2011 onwards. Although paradoxically during the year after the 2008 crisis, there was a GDP growth in the housing sector from 14.8 to 15.5 percent, the crisis in this sector was reflected macro - economically from 2011, when the GDP of the sector decreased one percentage point (to 14.5 percent). Despite the maintenance of the low-cost, high-profit housing production model, the market has registered a steady decline. With the objective of making the market more attractive and incentivizing the growth of the sector, in 2013 the housing policy was oriented to the change in the rules and regulations of the Housing Funds. Far from directing the offer to new localities, the changes had the effect of delaying the construction and financing processes, stagnating the economic acceleration of the sector.

From the above, in appearance the housing policy seeks to generate conditions to influence the creation of affordable housing for Mexican families. However, because of the low purchasing power and high prices of "social" housing, housing policy presents a structural limitation derived from an economic policy oriented to deregulation, decoupling from a production project and financing with a strategic development perspective linked to the social sphere.

With regard to social welfare, comparing the development model by import substitution against the neoliberal development path, the economic results are widely contrasting. If during the first model (1935-1982), the purchasing power of minimum wages increased 96.9\%; with the country's undertake in the second model, minimum wages lost $69.6 \%$ of their purchasing power, that is, they deteriorated to less than a third of those in 1982 (Damián, 2007). In addition, the government reduced the amount of subsidies for basic food products and increased the prices of public goods. Both policies raised the prices of tortilla, beans, milk, meat, among 
others, as well as water, transportation, electricity, gasoline, fertilizers, etc., affecting the level of consumption of the population and contributing to the increase of poverty (Damián, 2007).

Comparing the evolution of the proportion of poor people in Mexico in the light of the two development models referred above, the tendency towards the reduction in the proportion of the poor reached with the development model by import substitution reversed during neoliberalism. Figure 1.6 shows the comparison of three different poverty lines: that of the Economic Commission for Latin America and the Caribbean (ECLAC), the World Bank (WB) and that of the Normative Basket of Essential Satisfiers (CNSE) integrated by Boltvinik and Hernández Laos. From the period 1981 - 1984, poverty increased dramatically until 1996 and although it tends to decrease in the next four years, compared to the level of the year of departure, high levels of poverty persist.

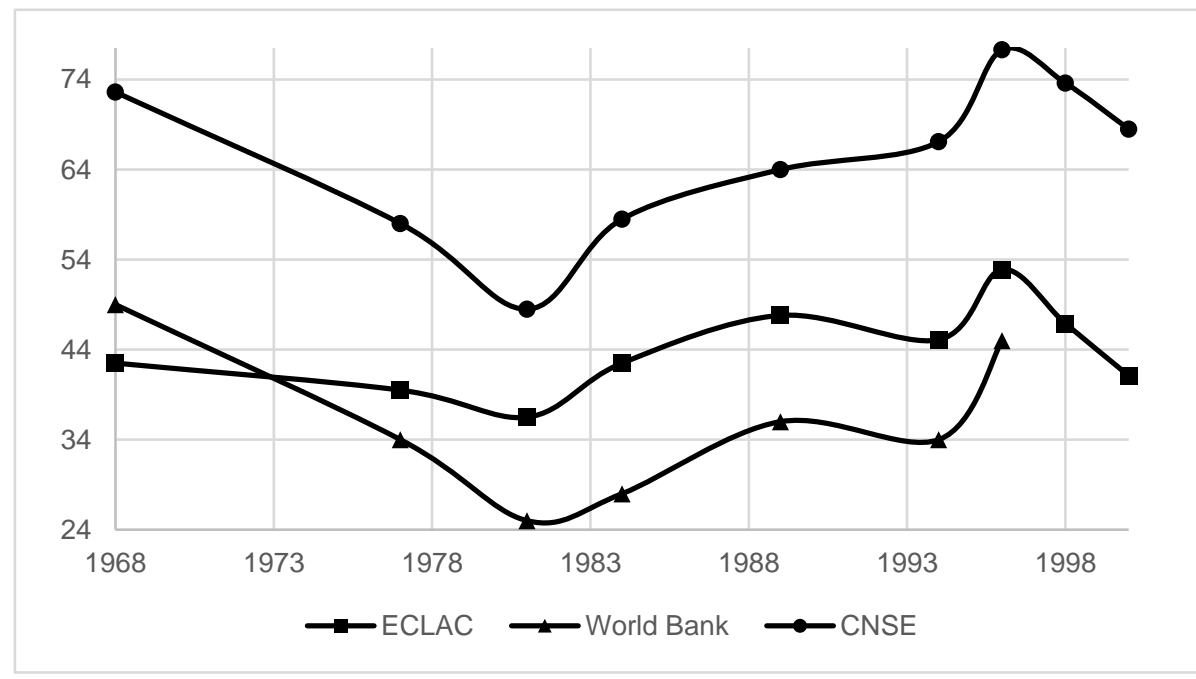

Figure 6. Percentage evolution of poverty in Mexico, 1968-2000. Various measurement methods

Source: Boltvinik (2013).

Boltvinik (2013) describes the dynamics of the rise of neoliberalism in Mexico (1981 - 1996) as one of the regressive trend of gradual increase in poverty, which reaches levels greater than 1968. In the three methods to measure poverty this increase is notorious: ECLAC registers an increase of 15.5 percentage points in this period, the BM data indicates an increase of 20 percentage points, and with the CNSE method the increase is 28.8 percentage points, which represents a serious setback. There is also a slight and insufficient reduction trend, where the incidence of poverty decreases again without reaching the levels of 1981 and the long-term margin in reference to the initial year of the contrast period is very small. For the year 2000, the percentage of the population in conditions of poverty by the ECLAC method is $41.1 \%$ and the CNSE measurement is $68.5 \%$, which represents a reduction of just 1.4 and 4.1 percentage points respectively in 32 years.

From the set of elements provided above, it is highlighted that the country's undertake of a neoliberal development path from the eighties of the twentieth century, and the abandonment of the industrialization strategy by import substitution, exerted a considerable influence on the evolution of population dynamics (including population characteristics and their spatial location in functional areas) of Mexico City. In addition, the free market boom has also shaped the dynamics of housing production and its public policy at the national level, influencing levels of urban poverty and inequality. Under this perspective, in the following section, an exercise will be carried out to measure poverty and inequality induced by lack of housing in Mexico City, as a result of the deindustrialization and depopulation processes promoted by neoliberalism in the country's capital.

\section{Measuring poverty and inequality induced by lack of housing in Mexico City from 2008 to 2015}

The notion of poverty induced by lack of housing $(\mathrm{PiH})$ represents a first approach that allows the evaluation of the costs impact associated with covering the population's housing needs as a condition of a poverty situation. As well as the scope of the national housing policy addressed in the previous section to avoid a situation of vulnerability of the inhabitants who lack their own housing. Camargo and Hurtado (2011), quoting Ruprah (2010), state that the concept of lack of housing-induced poverty refers to "the situation in which total 
income less housing expenditure (amortization fee or rental expenses, taxes on the property and maintenance costs of the house) is insufficient to acquire the basic family basket "(p. 234). In addition, the same authors quoting Kutty (2005), mention that "subsidies on housing expenditure significantly decrease the probability that households that are slightly above the poverty line will fall into it" (p. 235); This is why the PiH index also represents an indirect way of assessing the effectiveness of public housing policy in a given region.

Under the above conceptual logic, and taking into account that in Mexico City about half of the homes are in a condition of rent, loan or credit as shown in Figure 7; this section presents the calculation method and results of the PiH index in a period from 2008 to 2015 for the City and its 16 counties. This calculation exercise uses the Socioeconomic Conditions Modules (SCM) of the National Household Income Expenditure Surveys of the Mexican Statistics and Geography Institute (INEGI) in its publications of 2008, 2010, 2012, 2014 and 2015. It is important to mention that the design of the SCM survey itself, limits the level of reliability in the generation of results at federative entity. So that the value of the indicator set forth below presents greater validity in the case of Mexico City until 2014, since Statistics and Geography National Institute warns that the 2015 SCM edition is not comparable with previous modules. However, it is possible to consider the index obtained for the City and its counties in 2015 , as an indicative or proxy value to appreciate the economic social phenomenon under study.

Taking into account the conceptual elements and the statistical limitation set out above, the calculation of the $\mathrm{PiH}$ indicator is as follows. The average income of the population in a given region and period, minus the average of the average values of rent, loan and payment of housing credit, divided by the value of the food and non-food baskets for the specific calculation year. That is to say:

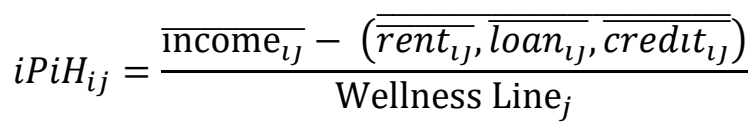

Where:

$i \mathrm{PiH}_{i j}=$ Index of Poverty induced by lack of Housing in the county $i$ in the year $j$

$\overline{\text { income }}_{i j}=$ Average income of the inhabitants in the county i in the year $j$

$\overline{r e n t}_{i j}=$ Average cost of housing rent in the county $i$ in the year $j$

$\overline{\text { loan }}_{i j}=$ Average cost of housing loan in the county $i$ in the year $j$

$\overline{\text { credit }}_{i j}=$ Average cost of housing credit in the county $i$ in the year $j$

Wellness Line $_{j}=$ Price of food + non food baskets in the year $j$

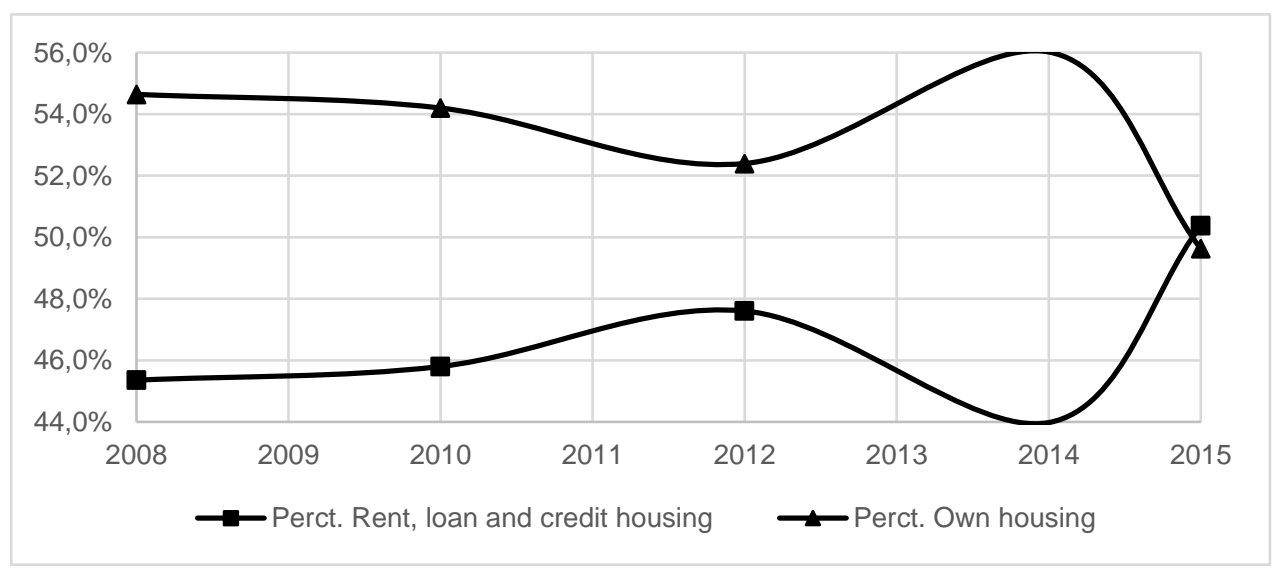

Figure 7. Percentage evolution in housing tenure in Mexico City 2008 - 2015

Source: Own elaboration with Socioeconomic Conditions Modules data 2008, 2010, 2012, 2014 and 2015.

Based on the previous equation, Table 2 shows the results of the calculation of the $\mathrm{PiH}$ index for the aforementioned years, as well as for the 16 counties and Mexico City. 
Table 2. Index of Poverty induced by lack of Housing (PiH) for Mexico City and its 16 counties

\begin{tabular}{|l|c|c|c|c|c|}
\hline \multicolumn{1}{|c|}{ County } & 2008 & 2010 & 2012 & 2014 & 2015 \\
\hline Alvaro Obregon & -0.7 & 1.1 & 1.2 & 0.8 & 0.3 \\
\hline Azcapotzalco & 1.3 & 1.3 & 0.5 & 1.4 & 0.6 \\
\hline Benito Juarez & 0.9 & 2.1 & 0.4 & 2.3 & 1.4 \\
\hline Coyoacan & 1.7 & 1.6 & 2.4 & 1.1 & -0.3 \\
\hline Cuajimalpa & 1.2 & -0.2 & 1.9 & 0.6 & 1.5 \\
\hline Cuauhtemoc & 1.3 & 0.8 & 1.6 & 1.1 & 1.0 \\
\hline Gustavo A. Madero & 1.2 & 1.0 & 1.1 & 0.8 & 0.7 \\
\hline Iztacalco & 1.0 & 1.0 & 1.0 & 0.2 & 0.6 \\
\hline Iztapalapa & 0.9 & 0.9 & 1.1 & 0.8 & 0.6 \\
\hline Magdalena Contreras & 0.7 & 0.4 & 0.7 & 1.6 & -0.2 \\
\hline Miguel Hidalgo & 1.5 & 1.2 & 1.8 & -0.2 & 2.4 \\
\hline Milpa Alta & 0.7 & 0.9 & 1.6 & 0.3 & 1.8 \\
\hline Tlahuac & 0.8 & 0.7 & 0.9 & 0.6 & 0.9 \\
\hline Tlalpan & 0.3 & 1.0 & 2.3 & 0.9 & 0.4 \\
\hline Venustiano Carranza & 1.8 & 1.1 & 0.9 & 0.8 & 1.0 \\
\hline Xochimilco & 0.1 & 0.7 & 1.3 & 0.6 & 0.8 \\
\hline Mexico City & 0.9 & 0.9 & 1.3 & 0.8 & 0.8 \\
\hline
\end{tabular}

Source: Own elaboration with Socioeconomic Conditions Modules data 2008, 2010, 2012, 2014 and 2015.

From the previous tabulation, the index for Mexico City had a relatively stable behavior during the analysis period. While during the years 2008 and 2010, it maintains a value of 0.9 ; in year 2012, it presents a significant increase reaching a value of 1.3; and then it decreases to 0.8 in the years 2014 and 2015. This implies that, on average, during 2008 and 2010, an inhabitant of the City who lacked his/her own home, after using his/her disposable income to meet this need through rent, loan or credit, was able to acquire only 90 percent of the value of the food and not food baskets. Increasing so his/her probability of falling into a condition of poverty. In 2012, the year in which the $\mathrm{PiH}$ index acquires a maximum value of 1.3 for the City; the same individual could acquire one hundred percent of the value of the baskets plus an additional 30 percent, observing a considerable improvement over the previous two years, overcoming the Welfare Line and thus escaping the condition of poverty. This situation is reversed in subsequent years (2014 and 2015), where the PiH index has a value of 0.8 , from which the individual once he/she meets his/her need for housing, can only access $80 \%$ of the value of the food and non-food baskets, once again at risk of falling into poverty.

The previous analysis highlights the importance of housing tenure as a conditioning factor of the population's poverty situation. Particularly of those who satisfy this basic need through rent, loan or credit, as the percentage of their disposable income destined to cover it, determines the capacity of residual income to acquire all food and non-food baskets or only a percentage of it. Figure 8 shows this, graphing the evolution of the ratio between the average costs associated with housing and the average income in Mexico City. The lowest value in the entire serie is in 2012, when the quotient acquires a value of just over 0.5. That is, on average, a person who lacked his/her own home used half of his/her income to solve that need. And with 50\% of its remaining disposable income he/she could acquire the value of food and non-food baskets, which represented $38.5 \%$ of its income in that year [see Figure 9], having conditions to save up to $11.5 \%$ of its income or allocate it to other expenses.

This relative favorable condition does not appear in the City in the years of analysis before and after 2012, when the PiH index takes values of 0.9 and 0.8 respectively. In 2010, on average, the individual who lacks a home allocates a little more than $60 \%$ of his/her income to the expenses associated to cover that need [see Figure 8] and percentages very close to $40 \%$ to acquire the food and non-food baskets [see Figure 9], a situation that places him/her in a vulnerable condition. In the second case, for the years 2014 and 2015, adverse conditions tend to be exacerbated compared to the years before 2012. In these years the individual allocates a percentage close to $70 \%$ of his/her income to cover the expenses associated with housing [see Figure 8 , for 2014 the ratio is 0.67], while the cost of the baskets absorbs just over 40\% of his/her income [see Figure 9], placing the person in a very probable condition of poverty. As already mentioned, according to the $\mathrm{PiH}$, in 2014 and 2015 the individual can only acquire $80 \%$ of food and non-food baskets with residual income after covering the cost of housing. 


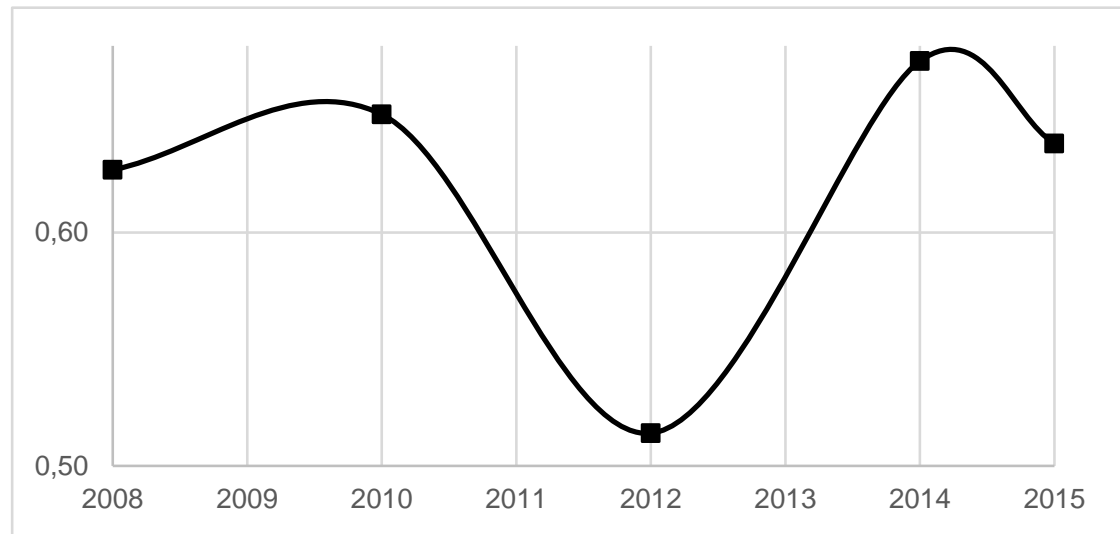

Figure 8. Percentage evolution of the quotient: Average of costs associated with housing / Average income in Mexico City 2008 - 2015

Source: Own elaboration with Socioeconomic Conditions Modules data 2008, 2010, 2012, 2014 and 2015.

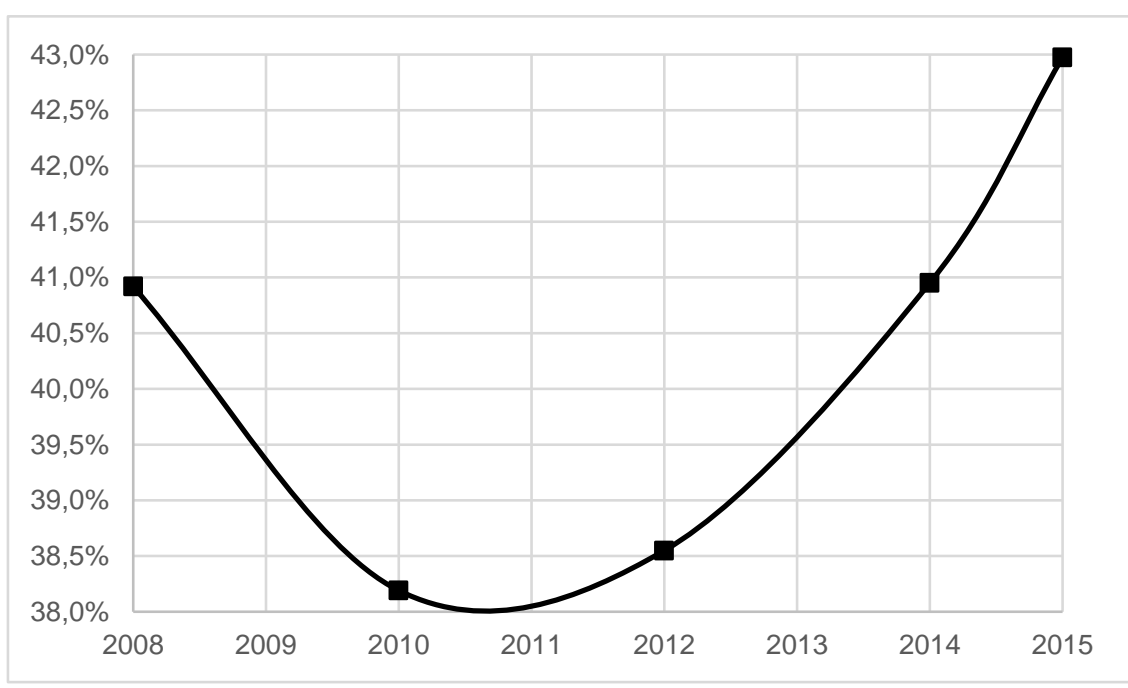

Figure 9. Percentage evolution of the quotient: Wellness Line / Average income in Mexico City 2008 - 2015

Source: Own elaboration with Socioeconomic Conditions Modules data 2008, 2010, 2012, 2014 and 2015.

Based on the index calculation of the population poverty induced by lack of housing between 2008 and 2015, it is possible to obtain a measure of the inequality of the inhabitants of the City based on their homelessness, as well as their space - scalar distribution in the country's capital. This indicator for the 16 counties of the City is the average of the $\mathrm{PiH}$ indices calculated in the years of analysis minus the $\mathrm{PiH}$ average of Mexico City. From this calculation, the inequality condition of the population induced by lack of housing of a certain county is understood as the differential between the situation of poverty induced by homelessness in that county in relation to the same situation in the City, having the latter as a reference for all counties. Table 3 presents the results.

Table 3. Average Index of Poverty by lack of Housing 2008 - 2015 and Inequality index induced by lack of Housing for Mexico City and its 16 counties

\begin{tabular}{|l|c|c|}
\hline \multicolumn{1}{|c|}{ County or functional area } & PiH Average 2008 - 2015 & $\begin{array}{c}\text { Inequality induced } \\
\text { by lack of Housing index }\end{array}$ \\
\hline Cuauhtemoc & 1.2 & 0.2 \\
\hline Miguel Hidalgo & 1.4 & 0.4 \\
\hline Venustiano Carranza & 1.1 & 0.2 \\
\hline Benito Juarez & 1.4 & 0.5 \\
\hline Central counties & 1.3 & 0.3 \\
\hline Azcapotzalco & 1.0 & 0.1 \\
\hline Gustavo A. Madero & 1.0 & 0.0 \\
\hline
\end{tabular}


Table 3 (cont.). Average Index of Poverty by lack of Housing 2008 - 2015 and Inequality index induced by lack of Housing for Mexico City and its 16 counties

\begin{tabular}{|l|c|c|}
\hline \multicolumn{1}{|c|}{ County or functional area } & PiH Average 2008 - 2015 & $\begin{array}{c}\text { Inequality induced } \\
\text { by lack of Housing index }\end{array}$ \\
\hline Alvaro Obregon & 0.5 & -0.4 \\
\hline Iztapalapa & 0.8 & -0.1 \\
\hline Coyoacan & 1.3 & 0.4 \\
\hline Iztacalco & 0.8 & -0.2 \\
\hline Adjacent counties & 0.9 & 0.0 \\
\hline Xochimilco & 0.7 & -0.2 \\
\hline Tlalpan & 1.0 & 0.0 \\
\hline Tlahuac & 0.8 & -0.1 \\
\hline Magdalena Contreras & 0.6 & -0.3 \\
\hline Cuajimalpa & 1.0 & 0.1 \\
\hline Milpa Alta & 1.0 & 0.1 \\
\hline Southern counties & 0.9 & -0.1 \\
\hline Total, Mexico City & 0.9 & 0.0 \\
\hline
\end{tabular}

Source: Own elaboration based on Table 2.

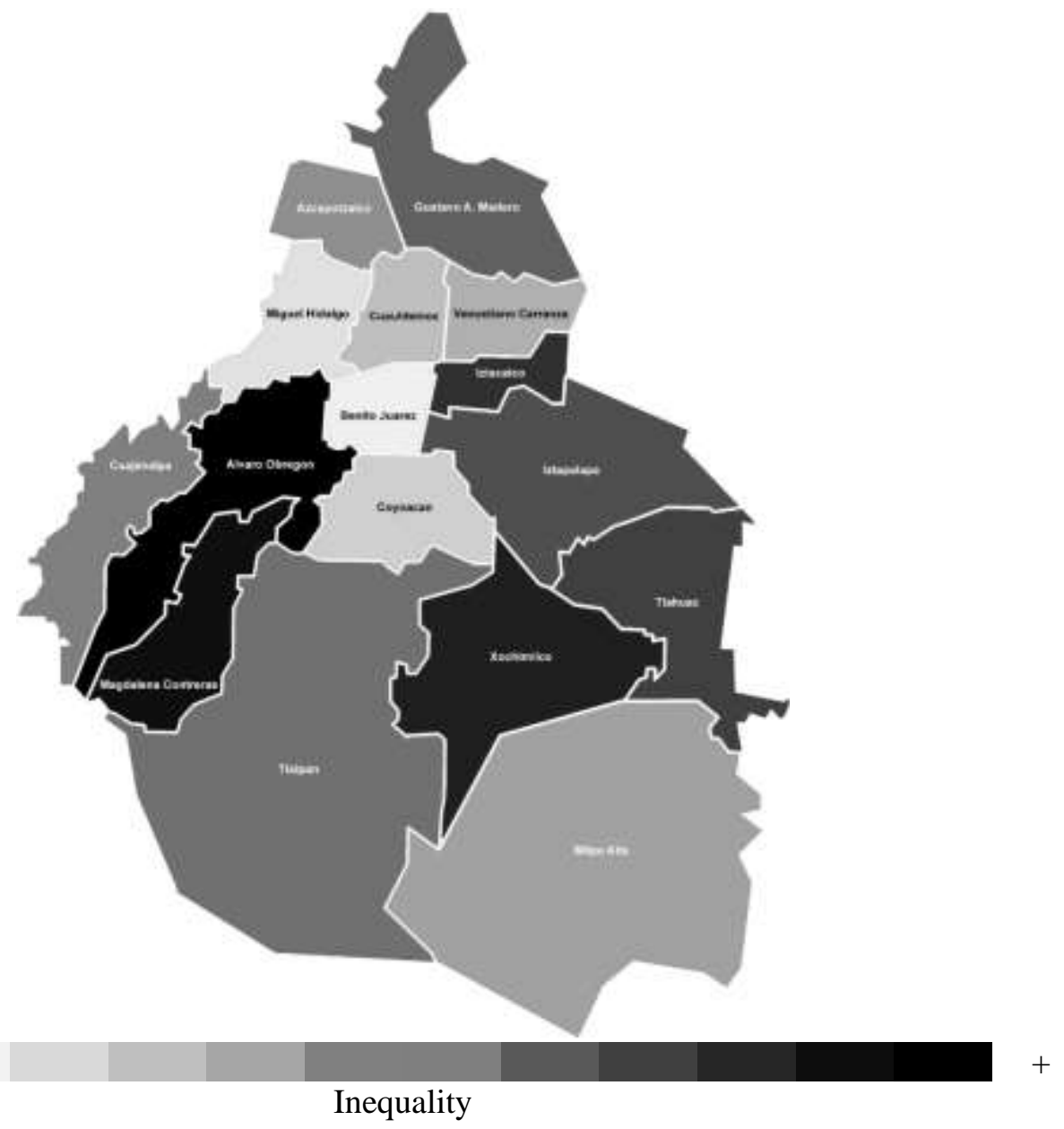

Map 1. Inequality induced by lack of Housing in Mexico City and its 16 counties

Source: Own elaboration based on Table 3.

The map of inequality induced by lack of housing in Mexico City [see Map 1] shows the Central City, which represents 9.6\% of the City's surface, consisting of the Cuauhtemoc, Miguel Hidalgo, Venustiano Carranza and Benito Juarez counties. This is a relatively homogeneous nucleus in which an average inhabitant of its population has the possibility of covering up to 40 percent more, the cost of food and non-food baskets after satisfying his/her need for housing (by rent, loan, or credit). As mentioned in the first section, this region had a strong process of deindustrialization from the 1990s onwards, as well as an expansion of the tertiary activities 
of the economy. Thus causing a double process of expulsion of the less economically favored population, first to the adjacent counties of Central City and gradually towards the metropolitan area of Mexico City. Then pulling in the population with greater economic resources, attracted by the quality of infrastructure, the boom in services, the real estate boom, as well as the public policy implemented between 2000 and 2006, that encouraged repopulation of the heart of the capital of the country.

A heterogeneous layer of counties where the inequality induced by lack of housing index tends to be more contrasting surrounds Central City. In this second layer of the City, which represents $28.8 \%$ of its surface, are the counties of Azcapotzalco and Gustavo A. Madero to the north. Their population barely manages to cover their basic needs after satisfying the need for housing. These two counties also underwent a process of deindustrialization from the 1990s, as well as a first process of housing the population expelled from Central City until the year 2000, later their population stagnate in subsequent years [see Figure 2]. The county of Coyoacan to the south is mostly oriented to services and the price of land has increased due to real estate boom speculation. In a similar way to Central City, the inhabitants of Coyoacan can acquire up to $30 \%$ more than the price of food and non-food baskets, after satisfying their housing needs. On the contrary, the counties of Alvaro Obregon to the west, and Iztacalco and Iztapalapa to the east of the City are the territories of greatest inequality of their inhabitants due to lack of housing in this second layer. In the first case, its inhabitants can only acquire half the value of the basic baskets after satisfying their need for housing; while in the case of the two delegations located to the east, this indicator hardly increases to $80 \%$ of the value of the baskets. Alvaro Obregon and Iztapalapa, have presented a consecutive process of depopulation from the nineties; while in Iztacalco there is an increasing trend in the population growth rate from 1990 to 2000, to then stagnate like the previous delegations, all adding to a gradual process of population expelling towards the municipalities of the adjacent states to Mexico City.

Southern counties are a last layer that surrounds Central City. There are the counties of Cuajimalpa, Magdalena Contreras, Tlalpan, Xochimilco, Tlahuac and Milpa Alta. They represent $61.6 \%$ of the surface of Mexico City and host different areas of natural conservation, having an agricultural tradition as the main economic activity. Therefore, the government has progressively discouraged human settlements in protected areas, promoting a depopulation process of this region and expulsion of its inhabitants to the metropolitan area of the City [see Figure 3]. The populations of this region present a clear situation of inequality induced to the lack of housing in relation to the inhabitants of Central City and Adjacent Counties. In no case of the Southern Counties, inhabitants can acquire an additional percentage of the basic baskets once they satisfy their need for housing [see Table 3], being in a very probable situation of poverty and social vulnerability.

\section{Conclusion}

Neoliberalism as a development modality undertaken by Mexico from the eighties of the last century shaped the production of space and housing in Mexico City. Deindustrialization paved the way to the emergency of tertiary sector activities and the concentration of services in the City. This configured an uneven development pattern, marked by low economic growth in recent decades, real estate speculation and weak public housing policy. These phenomena let the elites to shape the space, expelling the most disadvantaged population from the heart of the City and rising inequality among the inhabitants due to the lack of housing. Privileged spaces inhabitants in the central counties have a lower probability of falling into poverty, while the population of adjacent and southern counties subsist in conditions of social economic vulnerability.

That shows the need to rethink the pre-eminence of market as the most efficient agent for social resources distribution. Meanwhile the return of the State as a representative of common interests becomes a priority to promote new economic growth and to balance current Mexico City's inequalities of spatial development and housing production. The goal is to minimize its population poverty conditions, and social inequality linked to the lack of housing.

\section{References}

1. Boltvinik, J. (2013). Para Reformar la Reforma Social Neoliberal (que ha fracasado) y fundar un auténtico Estado de Bienestar en México [To Reform the Neoliberal Social Reform (which has failed) and found an authentic Welfare State in Mexico]. Estado y Comunes Revista de política y problemas públicos, (1), 57-94. DOI: https://doi.org/10.37228/estado_comunes.v1.n1.2013.3 
2. Boltvinik, J. (2012). Mexico's alleged influence on poverty reduction strategies in Latin America. Estudios Críticos del Desarrollo, II(2), 13-40. URL: https://estudiosdeldesarrollo.mx/estudioscriticosdeldesarrollo/wp-content/uploads/2019/01/ECD2-1.pdf

3. Caballero, J. (12 de octubre de 2016). Crecimiento del sector vivienda en los últimos años [Growth of the housing sector in recent years]. El Financiero [Newspaper]. URL: https://www.elfinanciero.com.mx/opinion/kpmg/crecimiento-del-sector-vivienda-en-los-ultimos-anos

4. Calva, J. (2004). La economía mexicana en perspectiva [The Mexican economy in perspective]. En J. Boltvinik, \& A. Damian, La pobreza en México y el mundo (pp. 100-132). México: Siglo XXI. URL: http://www.scielo.org.mx/scielo.php?script=sci_arttext\&pid=S1665-952X2004000100005

5. Camargo, A. \& Hurtado, A. (2011). Vivienda y pobreza: una relación compleja [Housing and poverty: a complex relationship]. Cuadernos de vivienda y urbanismo, 4(8), 224 - 246. URL: https://revistas.javeriana.edu.co/index.php/cvyu/article/view/5474

6. Damián, A. (2007). Los retos en materia social en México a inicios del siglo XXI [The challenges in social matters in Mexico at the beginning of the XXI century]. En J. Calva, (Coord.) Empleo, ingreso y bienestar (pp. $315 \quad$ 345). México. extension://ohfgljdgelakfkefopgklcohadegdpjf/https://www.ciad.mx/archivos/desarrollo/huescas/UNIV ERSALISMO.pdf

7. INEGI. (2008). Módulo de Condiciones Socioeconómicas de la ENIGH (MCS - ENIGH) 2008 [Socioeconomic Conditions Module of the National Household Income Expenditure Survey 2008]. Recuperado de: http://www.beta.inegi.org.mx/proyectos/enchogares/modulos/mcs/2008/default.html

8. INEGI. (2010). Módulo de Condiciones Socioeconómicas de la ENIGH (MCS - ENIGH) 2010 [Socioeconomic Conditions Module of the National Household Income Expenditure Survey 2010]. Recuperado de: http://www.beta.inegi.org.mx/proyectos/enchogares/modulos/mcs/2010/default.html

9. INEGI. (2012). Módulo de Condiciones Socioeconómicas de la ENIGH (MCS - ENIGH) 2012 [Socioeconomic Conditions Module of the National Household Income Expenditure Survey 2012]. Recuperado de: http://www.beta.inegi.org.mx/proyectos/enchogares/modulos/mcs/2012/default.html

10. INEGI. (2014). Módulo de Condiciones Socioeconómicas de la ENIGH (MCS - ENIGH) 2014 [Socioeconomic Conditions Module of the National Household Income Expenditure Survey 2014]. Recuperado de: http://www.beta.inegi.org.mx/proyectos/enchogares/modulos/mcs/2014/default.html

11. INEGI. (2015). Módulo de Condiciones Socioeconómicas 2015 [Socioeconomic Conditions Module of the National Household Income Expenditure Survey 2015]. Recuperado de: http://www.beta.inegi.org.mx/proyectos/enchogares/especiales/mcs/2015/

12. INEGI. (2017). Cuenta Satélite de la vivienda de México, 2016 [Mexican Housing Satellite Account, 2016]. Comunicado de prensa , Instituto Nacional de Estadistica y Geografía, Aguascalientes. chromeextension://ohfgljdgelakfkefopgklcohadegdpjf/https://www.inegi.org.mx/contenidos/saladeprensa/boleti nes/2018/StmaCntaNal/CSV2017.pdf

13. Kutty, N. (2005). A new measure of housing affordability: Estimates and analytical results. Housing Policy Debate, 16(1), 113 - 142. DOI: https://doi.org/10.1080/10511482.2005.9521536

14. Ruprah, I. (2010). Do social housing programs increase poverty?: An empirical analysis of shelter induced poverty in Latin America. OVE Working Papers 0510. Washington: Inter - American Development Bank - Office of Evaluation and Oversight (OVE). URL:https://www.academia.edu/5800502/Do Social Housing Programs Increase Poverty An Empiri cal Analysis of Shelter Induced Poverty in Latin America

15. Williams, M. (1997). La distribución del empleo en las delegaciones y los municipios de la ZMCM, 19881994 [The distribution of employment in the Mexico City Metropolitan Area, counties and municipalities, 1988-1994]. En R. Coulomb (Coord.), Dinámica urbana y procesos socio-políticos. Investigaciones recientes sobre la Ciudad de México (pp. 55-91). México: Observatorio Urbano de la Ciudad de México. chrome-extension://ohfgljdgelakfkefopgklcohadegdpjf/https://www.scielo.br/pdf/soc/v18n42/15174522-soc-18-42-00054.pdf 